\title{
INFLUENCE OF CARBON AND ADDITIVES ON THE HIGH-TEMPERATURE DECOMPOSITION BEHAVIOR OF PHOSPHOGYPSUM
}

\author{
VPLIV OGLJIKA IN DODATKOV NA VISOKO-TEMPERATURNI \\ RAZPAD FOSFORNEGA GIPSA
}

\author{
Rui Fang1, Hongbin Tan,3, Wenjie Mao², Xiaoling Ma1, Ying Feng1, Qian Jiang1, \\ Feihua Yang ${ }^{4}$ \\ ${ }^{1}$ State Key Laboratory of Environment-friendly Energy Materials, School of Materials Science and Engineering, Southwest University \\ of Science and Technology, Mianyang Sichuan 621010, China \\ ${ }^{2}$ Department of Electrical Engineering \&Information Technology, Shandong University of Science and Technology, \\ Jinan Shandong, 250031, China \\ ${ }^{3}$ Shaanxi Engineering Center of Metallurgical Sediment Resource, Shaanxi University of Technology, Hanzhong Shaanxi 723000, China \\ ${ }^{4}$ State Key Laboratory of Solid Waste Reuse for Building Materials, Beijing Building Materials Academy of Science Research, \\ Beijing 100041, China
}

Prejem rokopisa - received: 2019-09-19; sprejem za objavo - accepted for publication: 2020-08-05

doi:10.17222/mit.2020.083

The influence of carbon and iron additives on the high-temperature decomposition behavior of phosphogypsum (PG) is systematically investigated using XRD, SEM and EDS. In the absence of carbon, a small amount of anhydrite phase is decomposed after sintering at $1200{ }^{\circ} \mathrm{C}$ for $2 \mathrm{~h}$. However, the undesirable oldhamite phase is observed in RG/carbon50, $\mathrm{PG} / \mathrm{carbon} / \mathrm{FeSO} \mathrm{m}_{4} \mathrm{mix}-$ tures, $\mathrm{PG} / \mathrm{FeS}_{2}$ mixtures embedded in carbon after sintering at $800{ }^{\circ} \mathrm{C}$ for $2 \mathrm{~h}$, respectively, which implies a strong reducing atmosphere can promote oldhamite to generate. In the case of a PG/carbon 100 mixture, the diffraction peaks of anhydrite are not observed after sintering at $1100{ }^{\circ} \mathrm{C}$ for $2 \mathrm{~h}$. Moreover, the main phases in the mixture are found to be wollastonite-2M, larnite, calico-olivine, gehlenite and lime. Overall, the anhydrite decomposition to lime is mainly influenced by carbon and the sintering temperature.

Keywords: phosphogypsum, thermal decomposition, carbon, additives, reducing atmosphere, anhydrite phase

Avtorji v pričujočem članku opisujejo sistematično raziskavo vplivov dodatka ogljika in dodatkov železovih spojin na visoko temperaturni razpad fosfor-gipsa (PG). To je mavec, ki je nastal kot stranski produkt izdelave fosforne kisline. Raziskavo so izvajali z XRD, SEM in EDS. V odsotnosti ogljika je razpadel majhen del anhidritne faze med 2 urnim sintranjem na $1200{ }^{\circ} \mathrm{C}$ Vendar so opazili tudi prisotnost neželene oldhamitne faze (kubični $(\mathrm{Ca}, \mathrm{Mg}) \mathrm{S}$ ) v mešanicah RG/carbon50, $\mathrm{PG} / \mathrm{carbon} / \mathrm{FeSO} \mathrm{in}_{4}$ $\mathrm{PG} / \mathrm{FeS}_{2}$, ki so jih zakopali v ogljik in sintrali $2 \mathrm{~h}$ pri $800{ }^{\circ} \mathrm{C}$. To pomeni, da močna reduktivna atmosfera lahko pospešuje tvorbo oldhamita. V primeru mešanice PG/ogljik 100 , ki so jo sintrali $2 \mathrm{~h}$ na $1100{ }^{\circ} \mathrm{C}$ pa avtorji na difraktogramu niso opazili pikov, ki bi odgovarjali anhidritni fazi. Nadalje ugotavljajo, da so v mešanici prisotne glavne faze: volastonite-2M, larnit, kalicijev olivin $\left(\mathrm{Ca}_{2} \mathrm{SiO}_{4}\right)$, gehlenit $\left(\mathrm{Ca}_{2} \mathrm{Al}\left[\mathrm{AlSiO}_{7}\right]\right)$ in apno. Od tod sledi, da je razpad anhidrita $\mathrm{v}$ apno $\mathrm{v}$ glavnem odvisen od ogljika in temperature sintranja.

Ključne besede: fosfor-gips, termični razpad, ogljik, dodatki, reduktivna atmosfera, anhidritna faza

\section{INTRODUCTION}

Phosphogypsum (PG) is a major solid waste that is produced during phosphoric acid $\left(\mathrm{H}_{3} \mathrm{PO}_{4}\right)$ manufacturing by a wet acid process, and mainly consists of gypsum $\left(\mathrm{CaSO}_{4} \cdot 2 \mathrm{H}_{2} \mathrm{O}\right)$ and a minor amount of poorly crystalline $\mathrm{CaSO}_{4} \cdot 0.5 \mathrm{H}_{2} \mathrm{O}$ and crystalline $\mathrm{SiO}_{2}{ }^{1}$ In general, $\approx 4.5-5$ kilograms of $\mathrm{PG}$ is generated for every kilogram of $\mathrm{P}_{2} \mathrm{O}_{5}$. Moreover, almost 55 million tons of PG waste is annually generated in China and its annual output is estimated to be $\approx 280$ million tons worldwide., , $^{2}$ Despite the fact that the PG waste is utilized in numerous fields, such as soil-stabilization amendments, agricultural fertilizers, cement retarder, building bricks/blocks and cementitious binder, only a fraction of PG waste $(<40 w / \%)$ is reused

*Corresponding author's e-mail:

hb-t@163.com (Hongbin Tan) and a large proportion is treated by outdoor stacking, which induces additional costs and raises environmental concerns. ${ }^{3-5}$

The sustainable and effective recycling of PG can be realized by using it as a substitute for lime and sulfuric acid during the production process. ${ }^{6}$ It has been reported that the reductive decomposition of $\mathrm{CaSO}_{4}$ in the presence of $\mathrm{CH}_{4}, \mathrm{H}_{2}, \mathrm{C}$ and $\mathrm{CO}$ generates $\mathrm{SO}_{2}$ and lime, which can be utilized for the production of sulfuric acid and for acid-liquid neutralization, respectively. ${ }^{7-10}$ Thermal decomposition is usually recommended for the efficient recycling of PG; however, it has not been studied in detail. $^{7}$

Coal (carbon) is an industrial fuel, which can be utilized, as a heat source, to decompose PG and produce a reducing atmosphere, which further facilitates the PG decomposition. Herein, we present the influence of carbon 
on the thermal decomposition of PG, showing a deeper understanding of the given process.

The addition of iron additives to $\mathrm{CaSO}_{4}$ resulted in a marked reduction in the decomposition temperature of $\mathrm{CaSO}_{4}$, and the amount of unfavorable product $\mathrm{CaS}$ can decrease with an increase in the amount of additives; however, the interactive influence of iron additives and carbon on the $\mathrm{CaSO}_{4}$ decomposition has not been unveiled yet.

\section{EXPERIMENTAL PART}

Activated carbon and ferrous sulfate (analytical grade) were provided by Tianjin Dengke Chemical Reagent Co. Ltd., China. Pyrite (analytical grade) was provided by Strem Chemicals Inc., USA. PG (industrial grade) was provided by Sichuan Lomon Co. Ltd., China.

The chemical composition and X-ray diffraction (XRD) pattern of PG are presented in Table 1 and Figure 1, respectively. The PG contained $50.75 w / \% \quad \mathrm{SO}_{3}$, $37.88 w / \% \mathrm{CaO}, 7.20 w / \% \mathrm{SiO}_{2}, 0.88 w / \% \mathrm{P}_{2} \mathrm{O}_{5}$, etc. The $\mathrm{PG}$ phases were mainly of $\mathrm{CaSO}_{4} \cdot 2 \mathrm{H}_{2} \mathrm{O}$, a minor amount of $\mathrm{CaSO}_{4} \cdot 0.5 \mathrm{H}_{2} \mathrm{O}$, and $\mathrm{SiO}_{2}$.

Then, $1.0 \mathrm{~g}$ of PG was mixed with $0.5 / 1.0 \mathrm{~g}$ carbon powder, $0.5 \mathrm{~g}$ carbon and $0.15 \mathrm{~g}$ ferrous sulfate powder, and $0.5 \mathrm{~g}$ pyrite (PG/carbon 50/100, PG/carbon/FeSO ${ }_{4}$, $\mathrm{PG} / \mathrm{FeS}_{2}$ ), respectively. And then, the mixture was transferred into a $10-\mathrm{mL}$ covered ceramic crucible. To $\mathrm{PG} /$ carbon 50, PG/carbon/FeSO 4 , $\mathrm{PG} / \mathrm{FeS}_{2}$ mixture samples and according to references, ${ }^{11}$ the $10-\mathrm{mL}$ ceramic crucible was placed in a $100-\mathrm{mL}$ covered ceramic crucible, and filled with carbon. These crucibles were placed in a muffle furnace and heated at different temperatures, ranging from $800{ }^{\circ} \mathrm{C}$ to $1200{ }^{\circ} \mathrm{C}$, at a heating rate of $10{ }^{\circ} \mathrm{C} / \mathrm{min}$.

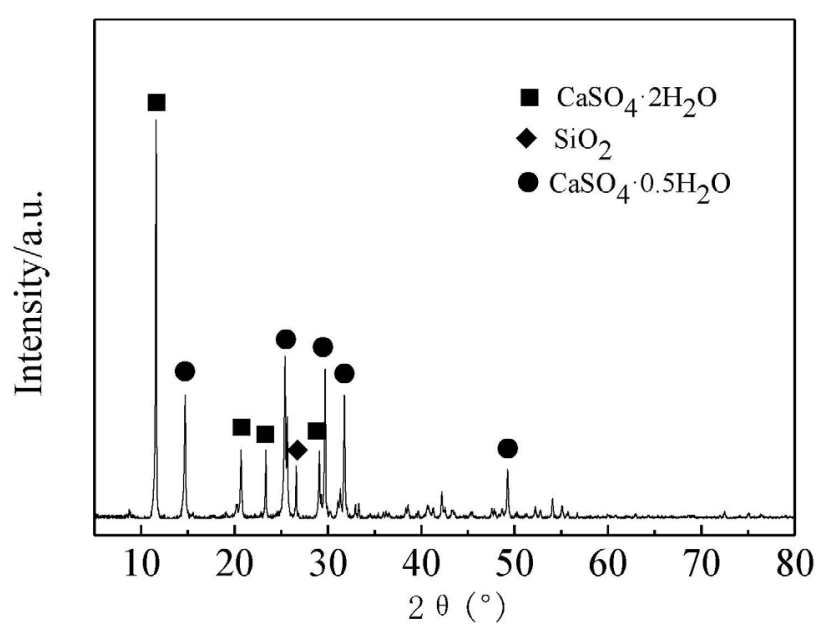

Figure 1: XRD pattern of PG

Table 1: Chemical composition of PG (w/\%)

\begin{tabular}{|c|c|c|c|c|c|c|c|c|}
\hline $\mathrm{CaO}$ & $\mathrm{SO}_{3}$ & $\mathrm{SiO}_{2}$ & $\mathrm{Al}_{2} \mathrm{O}_{3}$ & $\mathrm{P}_{2} \mathrm{O}_{5}$ & $\mathrm{Fe}_{2} \mathrm{O}_{3}$ & $\mathrm{SrO}$ & $\mathrm{K}_{2} \mathrm{O}$ & $\mathrm{MgO}$ \\
\hline 37.88 & 50.75 & 7.20 & 1.54 & 0.88 & 0.77 & 0.22 & 0.20 & 0.06 \\
\hline
\end{tabular}

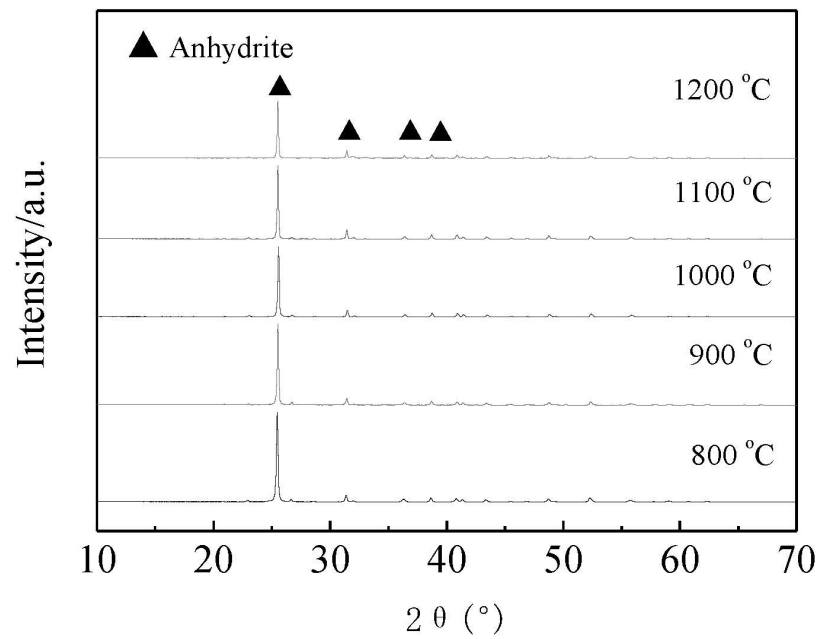

Figure 2: XRD patterns of PG calcined at different temperatures for $2 \mathrm{~h}$

X-ray diffraction (XRD) analysis was carried out by using an X'pert PRO X-ray diffractometer (PANalytical, Netherlands), equipped with $\mathrm{Cu}-K_{\alpha}$ radiation $(\lambda=$ $0,154178 \mathrm{~nm}$ ). The surface morphology was observed by using a scanning electron microscopye (SEM, TM-4000, Hitachi, Japan), equipped with an energy-dispersive spectrometer (EDS, 550i, IXRF, America) for compositional analysis.

\section{RESULTS AND DISCUSSION}

XRD patterns of $\mathrm{PG}$, calcined at different temperatures for $2 \mathrm{~h}$, are presented in Figure 2. The results reveal that the sample mainly consists of anhydrite phase $\left(\mathrm{CaSO}_{4}, \mathrm{PDF}\right.$ : 72-0619) after sintering in the temperature range $800{ }^{\circ} \mathrm{C}$ to $1200{ }^{\circ} \mathrm{C}$. However, the intensity of the diffraction peaks decreases with $\mathrm{n}$ aincreasing sintering temperature, indicating the decomposition of anhydrite phase.

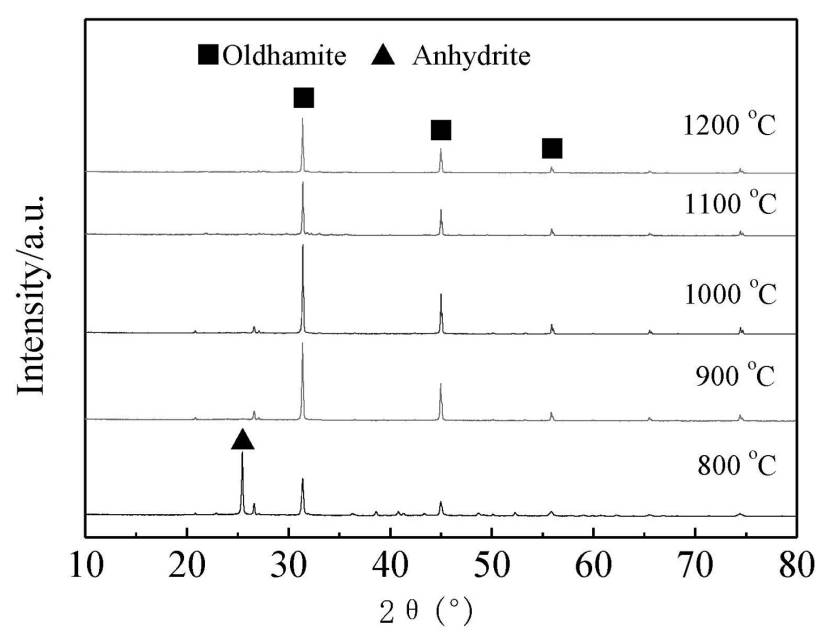

Figure 3: XRD patterns of RG/carbon 50 mixtures embedded in carbon and calcined at different temperatures for $2 \mathrm{~h}$ 
It has been reported that the $\mathrm{CaSO}_{4}$ slowly decomposes till the sintering temperature of $1200{ }^{\circ} \mathrm{C}$; however, the decomposition rapidly proceeds at $\mathrm{T}>1250{ }^{\circ} \mathrm{C}$. However, the initial decomposition temperature of $\mathrm{CaSO}_{4}$ is reduced by $20-50{ }^{\circ} \mathrm{C}$ and decomposition is completed before $1300{ }^{\circ} \mathrm{C}$ after the addition of $\mathrm{Fe}_{2} \mathrm{O}_{3} \cdot{ }^{12}$ Despite the presence of $\mathrm{Fe}_{2} \mathrm{O}_{3}$ in the $\mathrm{PG}$, the decomposition temperature remained lower than $1200{ }^{\circ} \mathrm{C}$, resulting in the minor decomposition of the $\mathrm{CaSO}_{4}$ phase. One should note that the high decomposition temperature consumes more energy and increases the operating costs. Therefore, carbon was added to reduce the decomposition temperature, which changed the reaction atmosphere and lowered the decomposition temperature.

XRD patterns of PG/carbon 50 mixtures embedded in carbon, calcined at different temperatures for $2 \mathrm{~h}$, are shown in Figure 3. The undesirable oldhamite product (CaS, PDF: 77-2011) is observed after calcination in the temperature range $800{ }^{\circ} \mathrm{C}$ to $1200{ }^{\circ} \mathrm{C}$. Only the diffraction peaks of oldhamite are observed by sintering in the temperature range $900{ }^{\circ} \mathrm{C}$ to $1200{ }^{\circ} \mathrm{C}$. According to the Reaction Module of FactSage software, the oldhamite is easily generated at low temperature $\left(>200{ }^{\circ} \mathrm{C}\right) .{ }^{7}$ Moreover, the catalytic role of $\mathrm{Fe}_{2} \mathrm{O}_{3}$ accelerates the reduction of $\mathrm{CaSO}_{4}$, resulting in the formation of CaS. Furthermore, the formation of a new intermediate phase, i.e., $\mathrm{CaFeSO}$, also inhibited the side reactions of sulfur release due to its excellent thermal stability. ${ }^{13}$ Briefly, both $\mathrm{CaS}$ and $\mathrm{CaO}$ were generated due to $\mathrm{CaSO}_{4}$ decomposition, as described below: ${ }^{13}$

$$
\begin{gathered}
2 \mathrm{C}+\mathrm{O}_{2} \rightarrow \mathrm{CO} \\
\mathrm{CaSO}_{4}+2 \mathrm{CO} \rightarrow \mathrm{CaS}+2 \mathrm{CO}_{2} \\
\mathrm{CaSO}_{4}+2 \mathrm{CO} \rightarrow \mathrm{CaO}+\mathrm{SO}_{2}+2 \mathrm{CO}_{2}
\end{gathered}
$$

It has been reported that the $\mathrm{CaS} / \mathrm{CaO}$ ratio depends on the reaction temperature and the $\mathrm{CO}$ concentration. Only oldhamite phase was observed after embedding the mixture in carbon and sintering in the temperature range

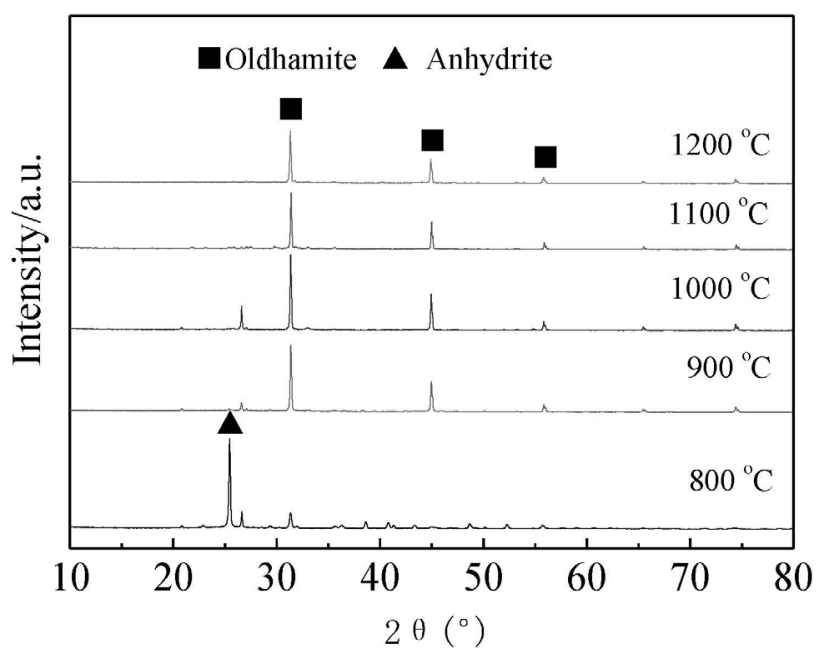

Figure 4: XRD patterns of $\mathrm{PG} /$ carbon/ $/ \mathrm{FeSO}_{4}$ mixtures embedded in carbon and calcined at different temperature for $2 \mathrm{~h}$
$900{ }^{\circ} \mathrm{C}$ to $1200{ }^{\circ} \mathrm{C}$. One should note that these samples experienced a strong reducing atmosphere due to the high concentration of $\mathrm{CO}$.

Furthermore, the XRD patterns of the PG/carbon/ $\mathrm{FeSO}_{4}$ mixtures embedded in carbon, calcined at different temperatures for $2 \mathrm{~h}$, are shown in Figure 4. Only the weak diffraction peaks of oldhamite are observed after sintering at $800{ }^{\circ} \mathrm{C}$. As seen from Figure 4, compared with Figure 3, the $\mathrm{FeSO}_{4}$ hinders the oldhamite generation, possibly because $\mathrm{FeSO}_{4}$ is easier to reduce than $\mathrm{CaSO}_{4}$. As a result, the reduction of $\mathrm{CaSO}_{4}$ is delayed.

XRD patterns of $\mathrm{PG} / \mathrm{FeS}_{2}$ mixtures embedded in carbon, calcined at different temperatures for $2 \mathrm{~h}$, are shown in Figure 5. The main phases are anhydrite and oldhamite after sintering at $800{ }^{\circ} \mathrm{C}$. As seen from Figure 5, compared with Figure 3, the diffraction peaks of oldhamite become weak after sintering at $1100{ }^{\circ} \mathrm{C}$, possibly because the oldhamite decomposed to $\mathrm{CaO}$. Further research is needed to continue to define these dependencies.

XRD patterns of $\mathrm{PG} /$ carbon 100 mixtures, calcined at different temperatures for $2 \mathrm{~h}$, are shown in Figure 6. At the calcination temperature of $900{ }^{\circ} \mathrm{C}$, the main phases are found to be anhydrite $\left(\mathrm{CaSO}_{4}\right.$, PDF: 72-0916), wollastonite-2M ( $\mathrm{CaSiO}_{3}$, PDF: 76-0186) and calico-olivine ( $\mathrm{Ca}_{2} \mathrm{SiO}_{4}$, PDF: 70-2450), a minor amount of quartz $\left(\mathrm{SiO}_{2}, \mathrm{PDF}\right.$ : 85-0457), larnite $\left(\mathrm{Ca}_{2}\left(\mathrm{SiO}_{4}\right)\right.$, PDF: 83-0460) and lime (CaO, PDF: 82-1690). At the calcination temperature of $1000{ }^{\circ} \mathrm{C}$, the main phases are wollastonite-2M, larnite, calico-olivine and gehlenite $\left(\mathrm{Ca}_{2} \mathrm{Al}(\mathrm{AlSi}) \mathrm{O}_{7}, \mathrm{PDF}\right.$ : 89-5917), and a minor amount of lime. Moreover, the diffraction peaks of anhydrite are not observed. These results confirm that the presence of carbon and the high temperature improved the decomposition of anhydrite and the formation of other phases. At the calcination temperature of $1100{ }^{\circ} \mathrm{C}$, the main phases in the mixture are the same as the sample calcined at

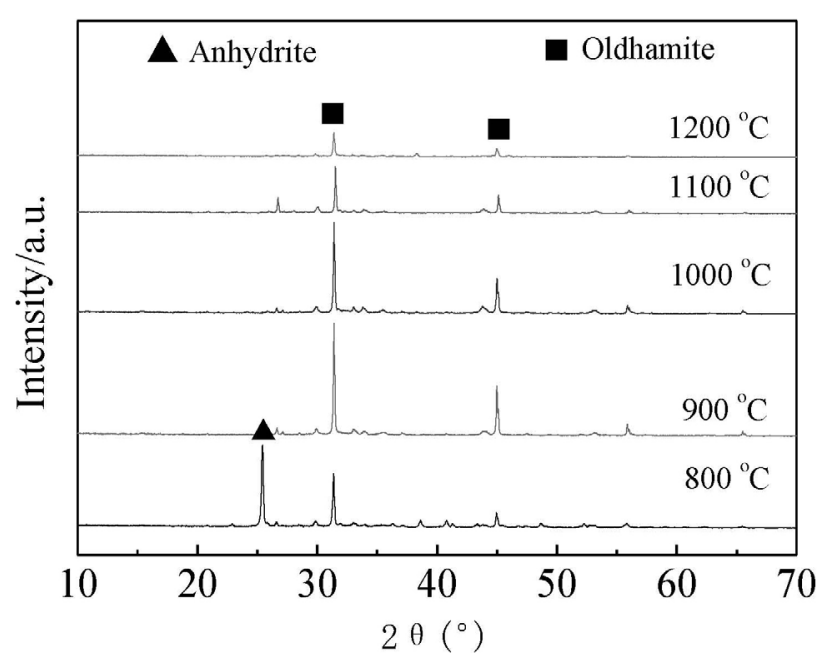

Figure 5: XRD patterns of $\mathrm{PG} / \mathrm{FeS}_{2}$ mixtures embedded in carbon and calcined at different temperature for $2 \mathrm{~h}$ 
$1000{ }^{\circ} \mathrm{C}$, but the content of gehlenite increases and the content of wollastonite-2M decreases.

Table 1 shows that the PG contains small amounts of $\mathrm{Al}_{2} \mathrm{O}_{3}$ and $\mathrm{SiO}_{2}$, whereas the XRD pattern shows strong diffraction peaks, corresponding to the wollastonite-2M and gehlenite phase. Moreover, the diffraction peaks of the lime phase were also observed. As mentioned earlier, the anhydrite decomposition depends on the reaction temperature and the CO concentration. ${ }^{14,15}$

One should note that the impurity phases in $\mathrm{PG}$, including $\mathrm{SiO}_{2}$ and $\mathrm{Al}_{2} \mathrm{O}_{3}$, accelerate the $\mathrm{CaSO}_{4}$ decomposition. ${ }^{16}$ Briefly, $\mathrm{CaSO}_{4}$ reacts with the impurity phases and yields composite oxides, as described below:6,16,17

$$
\begin{gathered}
\mathrm{CaSO}_{4}+\mathrm{SiO}_{2}+\mathrm{CO} \rightarrow \mathrm{CaSiO}_{3}+\mathrm{SO}_{2}+\mathrm{CO}_{2} \\
\mathrm{CaSO}_{4}+\mathrm{SiO}_{2}+\mathrm{CO} \rightarrow \mathrm{Ca}_{2} \mathrm{SiO}_{4}+\mathrm{SO}_{2}+\mathrm{CO}_{2} \\
\mathrm{CaSO}_{4}+\mathrm{Al}_{2} \mathrm{O}_{3}+\mathrm{SiO}_{2}+\mathrm{CO} \rightarrow \mathrm{Ca}_{2} \mathrm{Al}\left(\mathrm{AlSiO}_{7}\right)+ \\
+2 \mathrm{SO}_{2}+2 \mathrm{CO}_{2}
\end{gathered}
$$

On the other hand, $\mathrm{Fe}_{2} \mathrm{O}_{3}$ can improve the $\mathrm{CaSO}_{4}$ decomposition because a little of the $\mathrm{Fe}_{2} \mathrm{O}_{3}$ is present in PG. Moreover, $\mathrm{Fe}_{2} \mathrm{O}_{3}$ first reacted with $\mathrm{CaO}$ to form $\mathrm{Ca}_{2} \mathrm{Fe}_{2} \mathrm{O}_{5}$ and, then, the $\mathrm{Ca}_{2} \mathrm{Fe}_{2} \mathrm{O}_{5}$ phase reacted with $\mathrm{Fe}_{2} \mathrm{O}_{3}$ to produce $\mathrm{CaFe}_{2} \mathrm{O}_{4} \cdot \mathrm{Ca}_{2} \mathrm{Fe}_{2} \mathrm{O}_{5}(40.66 \%$ ), and $\mathrm{CaFe}_{2} \mathrm{O}_{4}(47.76 \%)$ phases are observed after sintering at $750{ }^{\circ} \mathrm{C}$ for $9 \mathrm{~h}$, whereas $\mathrm{CaFe}_{2} \mathrm{O}_{4}$ became the major phase after sintering at $850{ }^{\circ} \mathrm{C} .{ }^{18}$ The dense $\mathrm{CaSiO}_{3}$ ceramic with a densification temperature range of 930-970 ${ }^{\circ} \mathrm{C}$ are successfully fabricated via a traditional solid-state preparation process. ${ }^{19}$ The belite cements $\left(\mathrm{Ca}_{2} \mathrm{SiO}_{4}\right)$ were synthesized at low temperature $\left(1000{ }^{\circ} \mathrm{C}\right)$ by using silica fume and natural zeolite as the raw materials. ${ }^{20}$ In this work, the PG has $\mathrm{CaSO}_{4}$ and $\mathrm{SiO}_{2}$ with a thin diameter, and a low-melting-point impurity, such as $\mathrm{P}_{2} \mathrm{O}_{5}, \mathrm{~K}_{2} \mathrm{O}$, $\mathrm{CaF}_{2}$, etc., which can reduce the reaction temperature of the $\mathrm{CaSO}_{4}$ and $\mathrm{SiO}_{2}$.

The SEM image and EDS spectrum of the PG/carbon 100 , calcined at $1100{ }^{\circ} \mathrm{C}$ for $2 \mathrm{~h}$, are presented in Figure 7. Some nonuniform and irregular particles are ob-

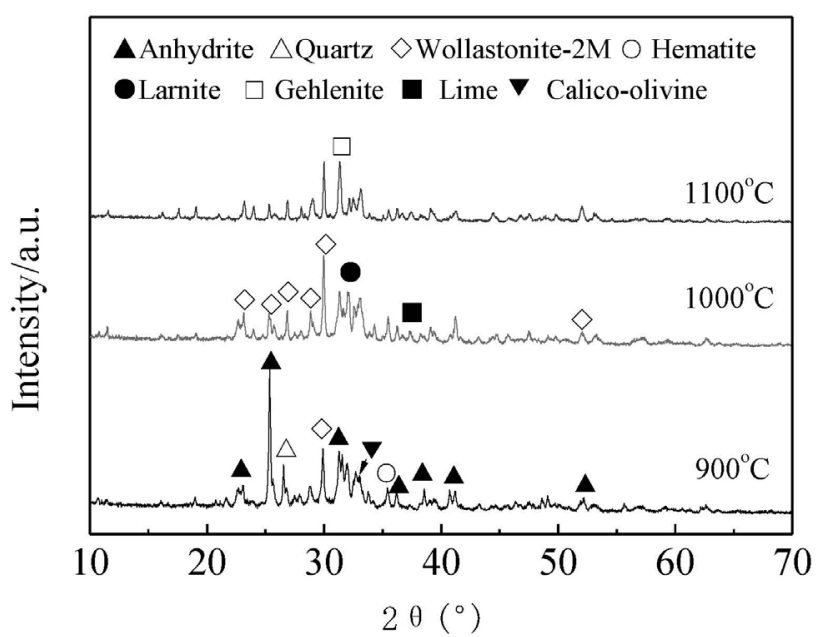

Figure 6: XRD patterns of PG/carbon 100 mixtures calcined at different temperature for $2 \mathrm{~h}$

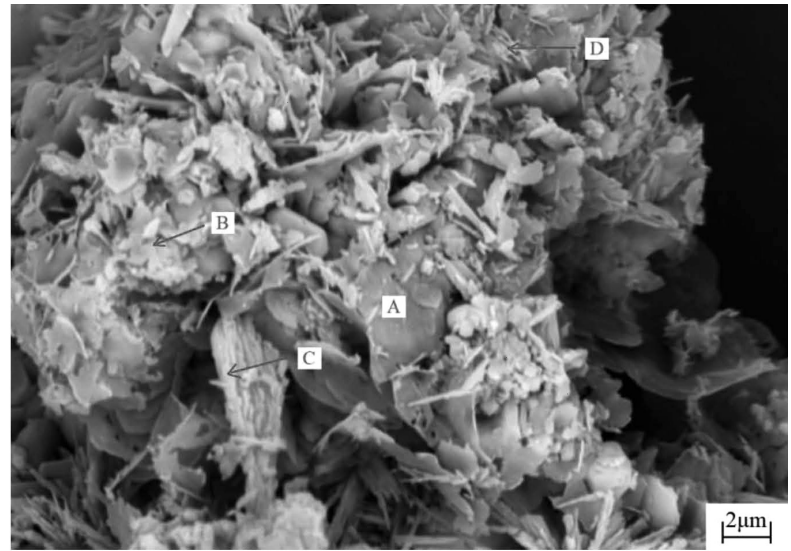

(A) (B)

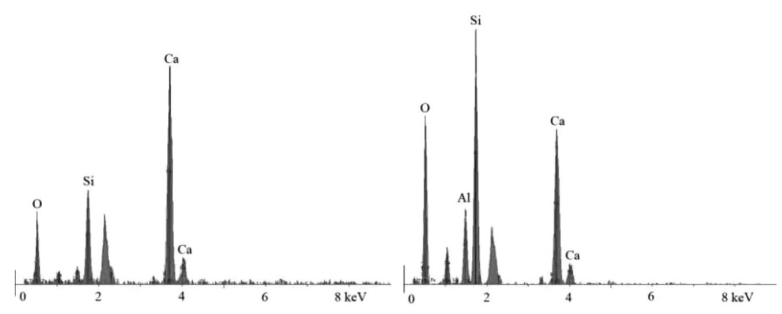

(C)

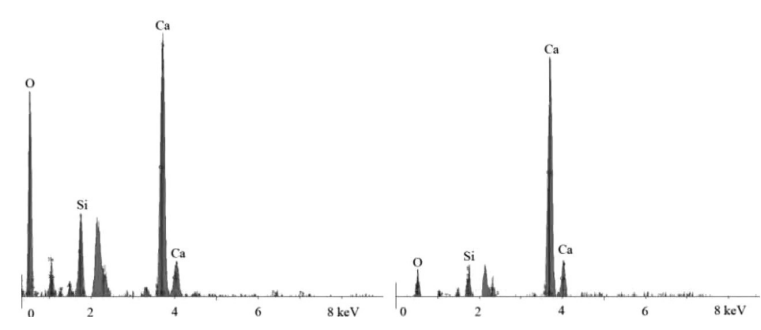

Figure 7: SEM image and EDS spectrum of PG/carbon 100 calcined at $1100{ }^{\circ} \mathrm{C}$ for $2 \mathrm{~h}$

served. The EDS analysis reveals that the particle (spot-A), with a smooth and molten morphology might be a larnite or calico-olivine (Figure 7a) ${ }^{21}$ On the other hand, the small flaky particle (spot-B) corresponds to the gehlenite (Figure 7b). Moreover, the coralloid particle (spot-C) represents the presence of $\mathrm{CaO}$ (Figure 7c). The whisker particle (spot D) corresponds to $\mathrm{CaO}$ with a $\mathrm{Si}$ and Fe background (Figure 7d).

\section{CONCLUSIONS}

In the absence of carbon, only a small amount of anhydrite decomposed after sintering at $1200{ }^{\circ} \mathrm{C}$ for $2 \mathrm{~h}$. Moreover, undesirable oldhamite products were observed after sintering in the temperature range $800{ }^{\circ} \mathrm{C}$ to $1200{ }^{\circ} \mathrm{C}$ in a PG/carbon50 mixture, PG/carbon/ $/ \mathrm{FeSO}_{4}$ mixtures, and $\mathrm{PG} / \mathrm{FeS}_{2}$ mixtures embedded in carbon, respectively.

After calcination at $1100{ }^{\circ} \mathrm{C}$ for $2 \mathrm{~h}$, the diffraction peaks of the anhydrite phase were not observed in the 


\section{R. FANG et al.: INFLUENCE OF CARBON AND ADDITIVES ON THE HIGH-TEMPERATURE DECOMPOSITION ...}

PG/carbon100 mixtures. The main phases were wollastonite-2M, larnite, calico-olivine and gehlenite, and a minor amount of lime. Interestingly, it can be concluded that the reducing atmosphere, provided by the carbon, renders a more prominent influence of anhydrite decomposition to lime than the $\mathrm{FeSO}_{4}$ and $\mathrm{FeS}_{2}$.

\section{Acknowledgements}

This work was supported by the Research Fund of the Sichuan Science and Technology Program of China (2019YFG0518) and Natural Science Foundation of Southwest University of Science and Technology (19zx7130).

\section{REFERENCES}

${ }^{1}$ O. Hentati, N. Abrantes, A. L. Caetano, S. Bouguerra, F. Gonçalves, J. Römbke, R. Pereira, Phosphogypsum as a soil fertilizer: Ecotoxicity of amended soil and elutriates to bacteria, invertebrates, algae and plants, J. Hazard. Mater., 294 (2015), 80-89, doi:10.1016/j.jhazmat. 2015.03.034

${ }^{2}$ M. Contreras, R. Pérez-López, M. J. Gázquez, V. Morales-Flórez, A Santos, L. Esquivias, J. P. Bolívar, Fractionation and fluxes of metals and radionuclides during the recycling process of phosphogypsum wastes applied to mineral $\mathrm{CO}_{2}$ sequestration, Waste. Manage., 45 (2015), 412-419, doi:10.1016/j.wasman.2015.06.046

${ }^{3}$ Y. Shen, J. Qian, J. Chai, Y. Fan, Calcium sulphoaluminate cements made with phosphogypsum: Production issues and material properties, Cement. Concrete. Comp., 48 (2014), 67-74, doi:10.1016/ j.cemconcomp.2014.01.009

${ }^{4} \mathrm{M}$. Zielinski,Influence of constant magnetic field on the properties of waste phosphogypsum and fly ash composites, Constr. Build. Mater., 89 (2015), 13-24, doi:10.1016/j.conbuildmat. 2015.04.029

${ }^{5}$ A. A. Cuadri, F. J. Navarro, M. García-Morales, J. P. Bolívar, Valorization of phosphogypsum waste as asphaltic bitumen modifier, J. Hazard. Mater., 279 (2014), 11-16, doi:10.1016/j.jhazmat.2014. 06.058

${ }^{6}$ N.Mihara, D.Kuchar, Y.Kojima, M.Hitoki, Reductive decomposition of waste gypsum with $\mathrm{SiO}_{2}, \mathrm{Al}_{2} \mathrm{O}_{3}$, and $\mathrm{Fe}_{2} \mathrm{O}_{3}$ additives, J. Mater. Cycles. Waste., 9 (2007) 1, 21-26, doi:10.1007/s10163-006-0167-4

${ }^{7}$ J. Yang, B. Zhu, L. Ma, H. Liu, Investigation of $\mathrm{Al}_{2} \mathrm{O}_{3}$ and $\mathrm{Fe}_{2} \mathrm{O}_{3}$ transmission and transformation during the decomposition of phosphogypsum, Chinese. J. Chem. Eng., 27 (2019), 1125-1131, doi:10.1016/j.cjche.2018.09.023

${ }^{8}$ X. Zhang, X. Song, Z. Sun, P. Li, J. Yu, Density functional theory study on the mechanism of calcium sulfate reductive decomposition by methane, Fuel, 110 (2013), 204-211, doi:10.1016/j.fuel.2012. 09.086

${ }^{9}$ H. Tian, Q. Guo, X.Yue, Y. Liu, Investigation into sulfur release in reductive decomposition of calcium sulfate oxygen carrier by hydrogen and carbon monoxide, Fuel. Process. Technol., 91 (2010), 1640-1649, doi:10.1016/j.fuproc.2010.06.013
${ }^{10}$ Z. Yan, Z. Wang, X. Wang, H. Liu, J. Qiu, Kinetic model for calcium sulfate decomposition at high temperature, T. Nonferr. Metal. Soc., 25 (2015), 3490-3497, doi:10.1016/S1003-6326(15)63986-3

${ }^{11}$ X. Ma, H. Tan, F. Dong, B. Li, J. Wang, X. He, C. Liu, Influence of troilite on the decomposition of ammonium jarosite and estimated activation energy, J. Therm. Anal. Calorim., 139 (2020), 933-939, doi:10.1007/s10973-019-08480-6

${ }^{12}$ Z. Yan, Z. Wang, H. Liu, Y. Tu, W. Yang, H. Zeng, J. Qiu, Decomposition and solid reactions of calcium sulfate doped with $\mathrm{SiO} 2, \mathrm{Fe} 2 \mathrm{O} 3$ and Al2O3, J.Anal.Appl.Pyrol., 113 (2015), 491-498, doi:10.1016/ j.jaap.2015.03.019

${ }^{13}$ Z. Di, F. Yang, Y. Cao, K. Zhang, Y. Guo, S. Gao, F. Cheng, The transformation pathways on the catalytic and stability-promoted $\mathrm{CaSO}_{4}$ reduction in CLC process using $\mathrm{Fe}_{2} \mathrm{O}_{3}$ supported, Fuel, 253 (2019), 327-338, doi:10.1016/j.fuel.2019.04.141

${ }^{14}$ Z. Miao, T. Wang, H. Yang, H. Zhang, X. Zhang, Utilization of Desulfurization Gypsum to Producing SO2 and Cao in Multi-Stage Fluidized Bed, International Symposium on Coal Combustion/ Cleaner Combustion and Sustainable World, (2011), 611-615, doi:10.1007/978-3-642-30445-3_84

${ }^{15}$ D. Zheng, H. Lu, X. Sun, X. Liu, W. Han, L. Wang, Reaction mechanism of reductive decomposition of FGD gypsum with anthracite, Thermochim. Acta, 559 (2013), 23-31, doi:10.1016/j.tca.2013.02. 026

${ }^{1}$ Z. Yan, Z. Wang, H. Liu, Y. Tu, W. Yang, H. Zeng, J. Qiu, Decomposition and solid reactions of calcium sulfate doped with $\mathrm{SiO}_{2}, \mathrm{Fe}_{2} \mathrm{O}_{3}$ and $\mathrm{Al}_{2} \mathrm{O}_{3}$, J. Anal. Appl. Pyrol., 113 (2015) 491-498, doi:10.1016/ j.jaap.2015.03.019

${ }^{16}$ Z. Zhang, Y. Wang, L. Zhu, J. Li, F. Wang, G. Yu, Performance of $\mathrm{Fe}_{2} \mathrm{O}_{3} / \mathrm{Al}_{2} \mathrm{O}_{3}$ oxygen carrier modified by $\mathrm{CaCO}_{3}$ and $\mathrm{CaSO}_{4}$ in chemical looping combustion, Appl. Therm. Eng., 160 (2019), 113813-113823, doi:10.1016/j.applthermaleng.2019.113813

${ }^{17}$ R. Wei, X. Lv, M. Yang, J. Xu, Effect of ultrasonic vibration treatment on solid-state reactions between $\mathrm{Fe}_{2} \mathrm{O}_{3}$ and $\mathrm{CaO}$, Ultrason. Sonochem., 38 (2017), 281-288, doi:10.1016/j.ultsonch.2017.03.023

${ }^{18}$ B. Touzo, K. L. Scrivener, F. P. Glasser, Phase compositions and equilibria in the $\mathrm{CaO}-\mathrm{Al}_{2} \mathrm{O}_{3}-\mathrm{Fe}_{2} \mathrm{O}_{3}-\mathrm{SO}_{3}$ system, for assemblages containing ye'elimite and ferrite $\mathrm{Ca}_{2}(\mathrm{Al}, \mathrm{Fe}) \mathrm{O}_{5}$, Cement. Concrete.Res., 54 (2013), 77-86, doi:10.1016/j.cemconres.2013.08.005

${ }^{19}$ S. Chen, X. Zhou, S. Zhang, B. Li, T. Zhang, Low temperature preparation of the $\beta-\mathrm{CaSiO}_{3}$ ceramics based on the system $\mathrm{CaO}-\mathrm{SiO}_{2}$ BaO- $\mathrm{B}_{2} \mathrm{O}_{3}$, J. Alloy. Comp., 505 (2010), 613-618, doi:10.1016/ j.jallcom.2010.06.090

${ }^{20}$ T. L. Ávalos-Rendóna, E. A. Pastén Chelala, C. J. M. Escobedo, I. A. Figueroa, V.H. Lara, L. M. Palacios-Romero, synthesis of belite cements at low temperature from silica fume and natural commercial zeolite, Mat. Sci. Eng. B., 229 (2018), 79-85, doi:10.1016/ j.mseb.2017.12.020

${ }^{21}$ G. Su, Y. Liu, L. Huang, H. Lu, S. Liu, L. Li, M. Zheng, Synthesis of hierarchical $\mathrm{Mg}$-doped $\mathrm{Fe}_{3} \mathrm{O}_{4}$ micro/nano materials for the decomposition of hexachlorobenzene, Chemosphere, 99 (2014), 216-223, doi:10.1016/j.chemosphere.2013.10.090 